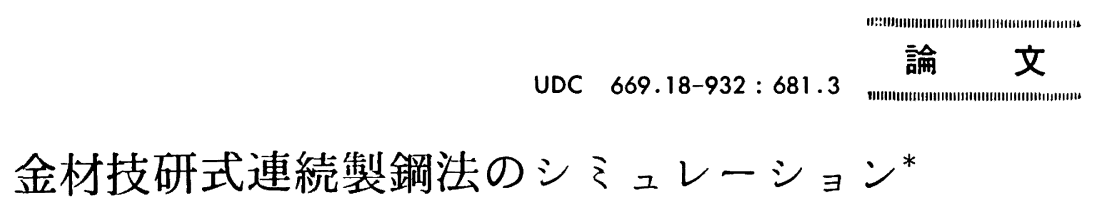

福沢 章**.中川龍一***.吉松史朗***.上田卓弥***

\title{
Simulation of the NRIM Continuous Steelmaking Process
}

Akira Fuxuzawa, Ryuichi Nakagawa, Shiro Yoshimatsu, and Takuya Ueda

\begin{abstract}
Synopsis
A mathematical model of the NRIM continuous steelmaking process has been developed on the basis of the assumption that the rate limiting step in the steelmaking reaction is mass transfer which is the function of flow rates of jetted oxygen and generated $\mathrm{CO}$ gas. Resistance constants in mass transfer equations and other system parameters used in the model are determined by the complex optimization method to get a good agreement with the actual data in steady state. Results applied for the start-up simulations for the NRIM process operations show that the model can represent the actual process with accuracy. This means that the parameter constants in steady state are available for the unsteady state simulation, so that the model can be used for an optimal designing of the continuous steelmaking process and for the development of the process control strategy. Moreover, the assumption that the gas flow rates have an important role for bath mixing can provide a valuable aid to understand the steelmaking reaction kinetics.
\end{abstract}

\section{1. 緒言}

金材技研式連続製鋼法は，製鉄体系の連続化の一環を なするのとして研究が進められてきたが，酸素製鋼法を 連続的に行なわせるだけとも見られる本方法も, 新しい プセス開発において生ずる幾多の問題からは不可避で あり，その装置と操業法の確立には種々の試みがなされ てきだ、ししかし実験規模が小さく，また実験を頻嫳に は行なえないなどの事情から, 装置あるいは操業法の選 択にあたつては種々の制限を受けざるを得なかつた。こ の制限を克服しかつ連続製鋼技術の可能性を知る目的で 金材技研式連続製鋼法に関する数学的モデルの開発を実

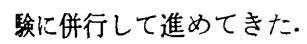

モデリングの対象である金材技研式連続製鋼炉は, 脱 $\mathrm{Si}$ ，脱 $\mathrm{P}$ を主とする第 1 段炉と脱 $\mathrm{C}$ を主とする第 2 段炉 で構成されており, その桶型の浴槽に酸素吹精ランスが 各段 4,5 本直列に取り付けられている複雑な反応器で あるため, モデルの作成には単純化に努め, 対象とする 成分変化が分析範囲にあり，また排㳯がより定常的に行 なわれる第1段炉を主体にモデリングに必要な各種定数 の探索を行なつた．ここではモデル作成の過程と, 操業 開始時についてシミュレートした結果について報告す る.

\section{2. モデルの構成}

製鋼反応過程の律速段階は, 高温での反応のため, 事 実上瞬間的に進行する化学反応ではなく, 拡散, 吸着な どの物理的要因にあると考えられている2) 5). 本モデル では製鋼反応を物質移動律速とみなし，下記の仮定に基 ういて作成された.

1 ）酸素吹精ランス 1 本で 1 つの完全混合槽を形成 し, 槽内の溶鋼, スラグの各成分濃度はそれぞれ均一で あり，熱的には溶鋼，スラグおよび排ガスは同一温度で あるとする。

2 ) 連続製鋼炉各段の混合特性は，その段に取付けら れたランス本数に等しい数の完全混合槽を直列に並べた もので代表できるとする.

3 ) 吹精酸素は一部は $\mathrm{FeO}$ としてスラグ相に含まれ， 残部は溶鋼中に吸収されるものとする.

4 ）製鋼反応は物質移動律速で進行するものとする. すなわち, 反応速度は反応成分の溶鋼内部での濃度と, スラグ相あるいは気相に平衡する濃度との差に比例し， 移動抵抗に反比例する.

5 ) 移動抵抗は，CO ガス生成反応では排ガス生成速 度に，溶鋼・スラグ間の反応では排ガス生成速度と送酸 速度の和に反比例するものとする.

\footnotetext{
* 昭和48年10月本会講演大会にて発表 昭和51年 3 月 29日受付 (Received March 29，1976)

** 金属材料技術研究所 (National Research Institute for Metals, 2-3-12 Nakameguro Meguro-ku 153)

*** 金属材料技術研究所工博 (National Research Institute for Metals)
} 
6) $\mathrm{CO}$ 生成反応におけるガス・溶湯界面の $\mathrm{C} ， \mathrm{O}$ 濃 度は $P_{\mathrm{CO}}=1 \mathrm{~atm}$ と平衡を保ちつつ推移する.

7 ) 溶湯・スラグ間の反応は, $(\mathrm{FeO})$ の還元は $(\mathrm{FeO})$ に平衡する酸素濃度 $\mathrm{O}_{\mathrm{eq}}$ 上溶晹中の酸素濃度O差に 応じて進み， Si，Mn，吕の酸化は，各元素のスラグ相に 平衡する濃度との差に応じて行なわれるものとし，この 場合（FeO）の還元を伴うものとする．浱度差が負にな つた場合は，上記の逆反応が物質移動律速にもとづいて 進行するものとする.

\section{1 界面反度}

以上の仮定に基づく物質の移動采統図を，ランス 1 本 について Fig. 1 に示す. これまで種々の仮定に基づく LD転炉のダイナミックモデルが提案されてきたが6) -8), 各段ごとに数本のランスを有する金材技研式連続製鋼法 に適用するには複雑すぎるため，単純でかつ酸素製鋼の 特徴をシミュレートできるものをということでこのモデ ルを作成した、仮定 $(5)$ は, 製鋼法の種類に関係なく酸素 供給速度と脱炭速度が広範囲にわたり比例関係にあり， 化学量論的関係を満たしていることから ${ }^{9) 10)}$ ，脱炭反応 が物質移動律速であり，その物質移動は吹込みあるいは 生成するガス流による鋼浴の拍汼に左右されるという仮 定に基づいたものである. 仮定 (5) で脱炭反応は排ガス (CO) 流量のみの関数としたのは, 鋼浴の攪捧が $\mathrm{CO} カ 5$ スに限られている鉄鉱石を酸化刘とした平炉製鋼法にお いても, 上述の酸素供給速度と脱炭速度の関係をほぼ満 たしていることによる. 同じく仮定 (5)で溶湯・スラグ 間の反応については吹精酸素量も覽找に影響を及ぼすと してあるが，これは L D 転炉操業の初期の脱炭反応が弱 い時期の溶湯・スラグ間の反応の進行を説明するためで ある. 鋼浴の㩇捧に対して吹精酸素シェットと生成 CO

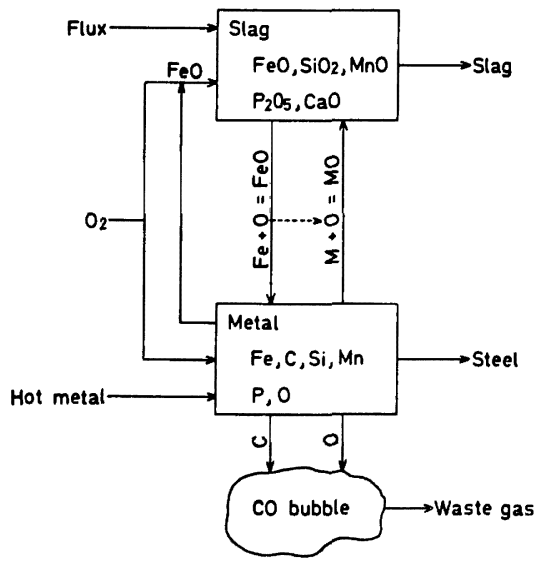

Fig. 1. Material flow in the model.
ガスの沸騰上昇のいずれが効果的かは，酸素吹精条件， 脱炭反忍の位置などにより変わると思われるが，ここで は移動抵抗 $R$ はガスの質量流量 $V$ に逆比例与るとした。 式で表わすと，

$\mathrm{CO}$ 生成反応 $R_{\mathrm{CO}}=\alpha_{\mathrm{CO}} / V_{\mathrm{CO}}$

溶湯・スラグ反応 $R_{j}=\alpha_{j} /\left(V_{\mathrm{CO}}+V_{\mathrm{O}_{2}}\right)$

ここで $\alpha$ は各反応に固有の比例定数 $(j=\mathrm{O}, \mathrm{M})$.

仮定 (6) に述べた $\mathrm{CO}$ 気泡と平衡する $\mathrm{C}, \mathrm{O}$ 浱度 $\mathrm{C}^{*}$, $\mathrm{O}^{*}$ は，溶湯から界面への両元素の移動量が $\underline{\mathrm{C}}+\underline{\mathrm{O}}=$ CO 反応を化学量論的に満たし，両元素に対する移動 抵抗は等しいと仮定することにより，二元連立方程式 ((3)，(4)式) の解として（5)式で与えられる.

平衡関係 $K_{\mathrm{CO}}=P_{\mathrm{CO}} /\left(\mathrm{C}^{*} \cdot \mathrm{O}^{*}\right)$

移動量 $\mathrm{O}-\mathrm{O}^{*}=\left(\underline{\mathrm{C}}-\mathrm{C}^{*}\right) \cdot 16 / 12$

$$
\begin{aligned}
\mathrm{O}^{*} & =\left\{\underline{\mathrm{O}}-4 \underline{\mathrm{C}} / 3+\left[(\underline{\mathrm{O}}-4 \underline{\mathrm{C}} / 3)^{2}\right.\right. \\
& \left.\left.+16 /\left(3 \cdot K_{\mathrm{CO}}\right)\right]^{1 / 2}\right\} / 2 \ldots \ldots \ldots \ldots \ldots
\end{aligned}
$$

$\left.\left(K_{\mathrm{CO}}=4.55 \times 10^{611}\right), 1500^{\circ} \mathrm{C}\right)$

仮定 ( 7 )における $\mathrm{O}, \mathrm{Si}, \mathrm{Mn}, \mathrm{P}$ のスラグとの平衡 濃度 $\mathrm{O}_{\mathrm{eq}}{ }^{11)}, \mathrm{Si}_{\mathrm{eq}}{ }^{11)}, \mathrm{Mn}_{\mathrm{eq}}{ }^{11)}, \mathrm{P}_{\mathrm{eq}}{ }^{12)}$ の值は以下の平衡 関係式を用いた。

$$
\begin{aligned}
& \log K_{\mathrm{O}}=\log \left(\left[\% \mathrm{O}_{\mathrm{eq}}\right] /\left(\gamma_{\mathrm{FeO}} \cdot N_{\mathrm{FeO}}\right)\right) \\
& =-6150 / T+2.604 \\
& \log K_{\mathrm{Si}}=\log \left(\left[\% \mathrm{Si}_{\mathrm{eq}}\right]\left[\% \mathrm{O}_{\mathrm{eq}}\right]^{2} /\left(\gamma_{\mathrm{SiO}_{2}} \cdot N_{\mathrm{SiO}_{2}}\right)\right) \\
& =-30720 / T+11.76 \\
& =6440 / T-2.95 \\
& =7 N_{\mathrm{Ca}}^{2+}+14660 / T-7.44 \text {. }
\end{aligned}
$$

(7) 式は飽和 $\mathrm{SiO}_{2}$ に関する平衡式を製鋼スラグに拡張 使用したものである.（6)，（7)，（8)式に使われてい る酸化物の活量係数は $\mathrm{CaO}-\mathrm{FeO}-\mathrm{SiO}_{2}$ 系の状態図で $N_{\mathrm{CaO}} / N_{\mathrm{SiO}_{2}}=2.5$ の線上の $N_{\mathrm{FeO}}=0.05 \sim 0.30$ の範囲 を 0.05 ごとに読みとつた各酸化物の活量係数の平均值 $\left(\gamma_{\mathrm{FeO}}=2.41^{13)}, \gamma_{\mathrm{SiO}_{2}}=0.01^{14)}, \gamma_{\mathrm{MnO}}=2.80^{13}\right)$ である.

\section{$2 \cdot 2$ 物贔収支}

仮定 (1)に基づいて連続製鋼炉の $i$ 番目のランスで構 成される完全混合槽 $i$ に流入する溶湯中の元素 $j$ の蓄積 速度は次式で与えられる。

$$
d W_{i} \cdot C_{\text {jout }} / d t=Q_{\text {in }} \cdot C_{j \text { in }}-Q_{\text {out }} \cdot C_{\text {jout }}-\Delta C_{j} / R_{j}
$$

ただし，スラグ・メタル反応 : $\Delta C_{j}=C_{\text {jout }}-C_{\text {jeq }}$, メタ ル・ガス反応 : $\Delta C_{j=C}=\left(\underline{\mathrm{C}}-\mathrm{C}^{*}\right) \cdot 28 / 12, R_{j}=R_{\mathrm{CO}}$

同様にスラグ相におけるjの酸化物 $k$ の蓄積速度は次 式で与えられる.

$d w_{i} c_{k \text { out }} / d t=q_{\text {in }} c_{k \text { in }}-q_{\text {out }} c_{k \text { out }}$ 
$+m_{k} \cdot J C_{j} /\left(m_{j} \cdot R_{j}\right)$

鋼浴中の $\mathrm{Fe}$ の蓄積速度は仮定 $(7)$ で述べたように $\mathrm{Si}$ ， $\mathrm{Mn}, \mathrm{P}$ の酸化の逆反応としてスラグから入つてくるこ と，および供給酸素の $\mathrm{FeO}$ 生成分配率 $X$ 考虑して次 式で表わされる.

$$
\begin{aligned}
& d W_{i} \cdot C_{\mathrm{Fe} \mathrm{out}} / d t=Q_{\mathrm{in}} \cdot C_{\mathrm{Fe} \text { in }} \\
& -Q_{\mathrm{cut}} \cdot C_{\mathrm{Fe} \text { out }}-\mathrm{O}_{2 \mathrm{in}} \cdot X \cdot m_{\mathrm{Fe}} / m_{\mathrm{O}} \\
& +\sum_{j \neq 0} m_{\mathrm{Fe}} \cdot J C_{j} /\left(m_{j} R_{j}\right) \\
& -m_{\mathrm{Fe}}\left(\mathrm{O}_{\text {out }}-\mathrm{O}_{\mathrm{eq}}\right) /\left(m_{\mathrm{O}} \cdot R_{\mathrm{O}}\right) \cdots \cdots
\end{aligned}
$$

スラグ中の $\mathrm{FeO}$ の蓄積速度は(12)式の右辺第三項以 下に相当する各項の符号が逆になり， $\mathrm{FeO} の$ 生成が正と なることから次式で表わされる.

$$
\begin{aligned}
& d w_{i} \cdot c_{\mathrm{FeO}} / d t=q_{\mathrm{in}} \cdot c_{\mathrm{FeO}} \text { in } \\
& -q_{\mathrm{out}} \cdot c_{\mathrm{FeO}} \text { out }+\mathrm{O}_{2 \mathrm{in}} \cdot X \cdot m_{\mathrm{FeO}} / m_{J} \\
& -\sum_{j \neq 0} m_{\mathrm{FeO}} \cdot J C_{j} /\left(m_{j} \cdot R_{j}\right) \\
& +m_{\mathrm{FeO}}\left(\mathrm{O}_{\mathrm{out}}-\mathrm{O}_{\mathrm{eq}}\right) /\left(m_{\mathrm{O}} \cdot R_{\mathrm{O}}\right)
\end{aligned}
$$

吹精された酸素のうち鋼浴中心萻積寸る涑度は次式で 表わされる.

$$
\begin{aligned}
& d W_{i} \cdot \mathrm{O}_{\text {out }} / d t=\mathrm{O}_{2 \mathrm{in}} \cdot(1-X) \\
& -Q_{\text {out }} \cdot \mathrm{O}_{\text {out }}-\left(\mathrm{O}_{\text {out }}-\mathrm{O}^{*}\right) \cdot 28 /\left(16 \cdot R_{\mathrm{Co}}\right) \\
& -\left(\mathrm{O}_{\text {out }}-\mathrm{O}_{\mathrm{eq}}\right) / R_{\mathrm{O}} \cdots \cdots \cdots \ldots \ldots \ldots \ldots \ldots \ldots \ldots \ldots \ldots \ldots \ldots \ldots \ldots \ldots \ldots \ldots
\end{aligned}
$$

ただし， $\mathrm{O}_{\text {out }}=\mathrm{O}$

以上がこのモデルの根本である物質収支の基本式であ るが，実計算においては，造㳯戍から入る $\mathrm{P} ，$ 末烧成て 残留している $\mathrm{CaCO}_{3}$ あるいは鉄鉱石の分解考若して 微分方程式を構成した。

\section{3 熱収支}

物質収支の場合と同様に，i槽における熱量 $H_{i}$ の蓄 皘速度は流入熱量 $H_{\mathrm{in}}$, 流出熱量 $H_{\text {out }}$, 反応熱 $H_{r}$ お よび熱損 $H_{l}$ の関数こして次式で表わされる.

$$
\begin{aligned}
& d H_{i} / d t=H_{\mathrm{in}}-H_{\text {out }}+H r-H l \\
& H_{\text {in }}=\Sigma C_{p n} \cdot J T_{n} \cdot U_{n} \ldots \ldots \ldots \ldots \\
& H_{\text {out }}=\Sigma C_{p p} \cdot J T_{p} \cdot U_{p} \ldots \ldots \ldots \ldots
\end{aligned}
$$

ただ， $C_{v n, p}$ は流入流出物質の比熱, $J T_{n, p}$ は流 入, 流出物質温度と標準温度 $\left(1600^{\circ} \mathrm{C}\right)$ との温度㾏, $U_{n, p}$ は流入, 流出物質の流量である. 仅定 (1)で述べたよう に $J T_{p}$ はいずれの流出物質も同一温度である.

反応熱生成速度 $H_{r}$ は各成分の酸化，吹精酸素による $\mathrm{Fe}$ の酸化，スラグからメタルへの $\mathrm{FeO}$ の分解および造 㳯绪，鉄鉱石の分解あるいは生成酸化物の複塩生成によ る反応熱の和として次式で表わされる.

$$
\begin{aligned}
H_{r} & =\Sigma \Delta H_{j}\left(C_{\text {jout }}-C_{\text {jeq }}\right) / R_{j} \\
& +\Delta H_{\mathrm{Co}}\left(C_{\mathrm{out}}-C^{*}\right) m_{\mathrm{Co}} /\left(m_{\mathrm{C}} R_{\mathrm{Co}}\right) \\
& +\Delta H_{\mathrm{FeO}}\left(\mathrm{O}_{2 \mathrm{in}} \cdot X \cdot m_{\mathrm{FeO}} / m_{\mathrm{O}}\right.
\end{aligned}
$$

$$
\left.-\Sigma m_{\mathrm{FeO}}\left(C_{\text {jout }}-C_{\text {jeq }}\right) /\left(m_{j} R_{j}\right)\right)+h_{D} \cdots \cdots(
$$

$$
\text { ただし， } C_{\text {out }}=\mathrm{G}
$$

熱損は次式で規定した。ここで熱損失係数 $H L$ は, 熱 損が製鋼炉への流入熱量と反応熱の和に比例寸るとして 実操業の結果から求めた定数である.

$$
H l=H L\left(H_{\mathrm{in}}+H r\right)
$$

これらの関係式を基本としてモデルを構成した。連続 製鋼法のシミュレーションは微分方程式 $(10) 〜(15) を$, 対象と寸る製鋼炉の操業条件で決をる初期条件と境界条 件および $2 \cdot 1 て ゙$ 規定した境界条件のもとに数值計算を行 うことにより得られる。モデルと実㭁の憍渡しとなる抵 抗定数なよ゙のパラメータ, 混合特性あるいは熱損の決定 は次のようである。

\section{3. 各種定数の決定}

\section{1 最適値の探索}

モデルと連続製鋼法の操業結果を関連ゔけるシステム ハラメータとして反応の抵抗係数 $\alpha_{\mathrm{CO}}, \alpha_{\mathrm{O}}, \alpha_{\mathrm{Si}}, \alpha_{\mathrm{Mn}}$, $\alpha_{\mathrm{P}}$, 吹精酸素の $\mathrm{FeO}$ 生成に消費される割合である酸素 分配係数 $X$ ，および酸素効染 $\mathrm{O} E$ (吹精酸素に対する $\mathrm{Fe}$, $\mathrm{C}, \mathrm{Si}, \mathrm{Mn}, \mathrm{P}$ の酸化に供された酸素量の割合)の 7 因 子を選び，コンプレックス法15) 17)によりとの数值を決 定した，非線形系に対する最適化法の1つであるコンプ レックス法は, 他の類似の最適化法と同栤, 最適化の過 程索判別するための目的関数と, より最適值に近い值を 与えるパラメータを探索し対象となるモデル（ここでは 連続製鋼モデル）に送る機能とを有する主プログラム上， その值に基づいてモデルの計算を行ない目的関数の变数 の計算綕果を主プログラムに送り返す副プログラムから なり，目的関数が実用上十分な範囲に入るまでハラメー 夕の探索, 目的関数の判定を繰返し計算を行なうもの である. 目的関数は実操業の定常状態における流出溶 湯の C, Si, Mn, P 濃度, 出湯温度, スラグ中の $\mathrm{FeO}$ 浱度でモデルの詮算の絬果得られたそれぞれ対応寸る值 を除した值の対数をとり，その2 推和で定莪した。これ により目的関数が0に近づくにど計算結果が実測值に近 いと判定できる.

副プログラムは実炉に邻したものとするた心，2に述 ベた基本モデルに次項以降の炉内の混合特性, 熱損頂, 装入鉄鉱石の条件を組込えで作成した。

\section{$3 \cdot 2$ 製銅炉内の混合特性}

モデルの反応に関寸るパラメータを決める上で, 求め うる装置定数は可能な限り明らかにせ称ばならないか， 連続式反応器内の混合特性花知ることは不可欠なものて 
ある. 長さ $3 \mathrm{~m}$, 幅 $30 \mathrm{~cm}$, 静止鋼浴深さ $15 \mathrm{~cm}$ の連 続製鋼炉内1) に，溶湯流入側から炉の中央部にかけて 4 本のランスを配列した反応器の混合状態は非常に複雑で あるが18，仮定（1)，（2）に基づいて Fig. 2 に示すよ うに溶湯とスラグについて，それぞれ直列に並べられた 4 つの完全混合槽で 1 つの製鋼炉を構成与るものとし た．各ランス（槽）が分担する溶湯とスラグの重量（滯 留量）は，ランスが製鋼炉の流入側に等間隔に配列され ていることから，流入側の 3 槽は同一滞留量を有し，第 4 槽の滞留量は全滯留量から先の 3 槽分を引いたものと して求めた混合特性の計算結果上，トレーサーとして溶 湯には Cu 粉，スラグにはフェロチタンの小粒を用いた パルス応答の実測值を対応させて決定した。

\section{$3 \cdot 2 \cdot 1$ 鋼浴の混合特性}

鋼浴の混合特性に関与るブロック線図は Fig. 3 a)で 示される，第 $i$ 槽の伝達関数 $G_{i}$ は次式で表わされる.

$$
G_{i}-C_{i}(s) / C_{i-1}(s)=1 /\left(s \cdot W_{i} / Q+1\right)
$$

製鋼炉全体の混合に開与る任達関数 $G$ は $G_{i}$ の積として 次式で表わされる.

$$
G=C_{4}(s) / C_{0}(s)=G_{1} \cdot G_{2} \cdot G_{3} \cdot G_{4}
$$

ここで流入側 3 槽の滞留量は等しいとした仮定条件から $W_{1}=W_{2}=W_{3}$ であることを考慮して (20)式を(21) 式に

Flux

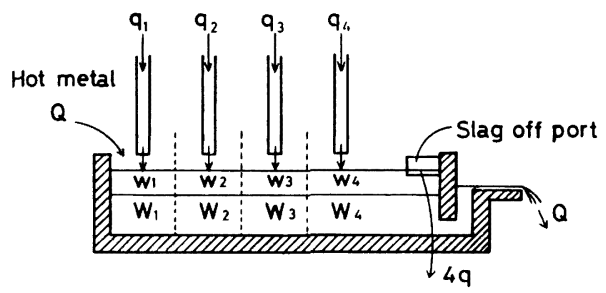

Fig. 2. Schematic representation of the application of back-mix model to the continuous steelmaking furnace.

\section{a. Metal}

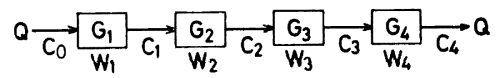

\section{b. Slag}

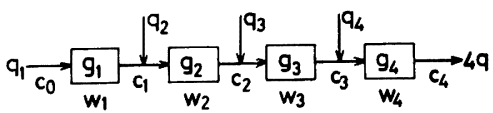

Fig. 3. Bath mixing block diagrams for metal and slag.
代入して整理すると次式となる.

$$
G=1 /\left[\left(s W_{1} / Q+1\right)^{3}\left(s W_{4} / Q+1\right)\right]
$$

これが連続製鋼炉鋼浴の伝達関数である.この系にトレ 一サーをインパルス $C_{0}(s)=C^{0} W / Q$ で入れた場合の 出口側の応答は

$$
C_{4}(s)=\left(C^{0} W / Q\right) /\left[\left(s W_{1} / Q+1\right)^{3}\left(s W_{4} / Q+1\right)\right]
$$

ただし， $W=W_{1}+W_{2}+W_{3}+W_{4}$

これをラプラス逆変換することにより，求める滯留時間 分布は次のようになる。

$$
C_{4}=\left[\left(A_{1}+A_{2} t+A_{3} t^{2}\right) e^{a t}-A_{1} e^{b t}\right] Q^{3} W C^{0} /\left(W_{1}^{3} W_{4}\right)
$$

$$
\text { ただし, } \begin{aligned}
A_{1} & =1 /(a-b)^{3}, A_{2}=-1 /(a-b)^{2}, \\
A_{3} & =0.5 /(a-b), a=-Q / W_{1}, b=-Q / W_{4}
\end{aligned}
$$

この式に操業条件 $W=1000 \mathrm{~kg}, Q=130 \mathrm{~kg} / \mathrm{min}$ を 代入し， $W_{1}$ を変えた場合の滞留時間分布の変化を Fig. 4 に示す。図中に実炬における滞留時間分布の実測結果 を合わせてプロットしたが，第1段炬にトレーサーを投 入した第 59，60 回実験のプロットと計算結果を比較し $\tau W_{1}=200 \mathrm{~kg}, W_{4}=400 \mathrm{~kg}$ の值を第 1 段炉の各ランス が分担する溶湯滯留量とした。第 57,58 回実験におけ る第 2 段炉の滯留時間分布の実測結果を同図にプロット したが，ピークが第 1 段炉より早いのは，第 2 段炉が脱 炭を主としているため炉内の CO ボイルによる激しい攪 拌が行われていることの例証であり，完全混合槽により 近いといえる.

\section{$3 \cdot 2 \cdot 2$ スラグの混合特性}

スラグの滯留時間分布に関するブロック線図をFig. 3 b ）に示す．溶楊の場合と異なり，各ランスから造涬剂 が均等に酸素と同時供給されるため，各槽へ入る造滓刘 流量 $q$ は供給造浑剂流量と溶湯中の $\mathrm{Si}, \mathrm{Mn}, \mathrm{P}$ および $\mathrm{Fe}$ の酸化物生成速度の和をラン ス本数で等分したもの とした．鋼浴と同様 $i$ 槽のスラグ相の伝達関数 $g_{i}$ は次 式で与えられる。

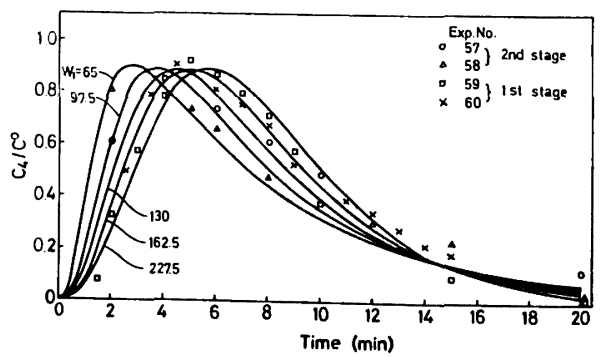

Fig. 4. Impulse response in the metal bath based on back-mix reactors in series. 


$$
g_{i}=1 /\left(s w_{i} / i \cdot q+1\right)
$$

スラグ相全体の伝達関数 $g$ は，各ランスから供給される 造㵏削化よるトレーサーの希釈， $c_{i}{ }^{\prime}=i c_{i} /(i+1)$ ，を考 虑して,

$$
\begin{aligned}
& g=c_{4}(s) / c_{0}(s)=g_{1} \cdot g_{2} \cdot g_{3} \cdot g_{4} / 4 \\
& =1 /\left[4\left(s w_{1} / q+1\right)\left(s w_{2} / 2 q+1\right)\right. \\
& \left.\left(s w_{3} / 3 q+1\right)\left(s w_{4} / 4 q+1\right)\right] \ldots \ldots \ldots . . .
\end{aligned}
$$

この系にインパルス $c_{0}(s)=c^{0} w / q$ が入つた場合の出口 側の応答は, ラプラス逆变換して次式で与えられる。

$$
\begin{aligned}
c_{4} & =6\left(A_{1} e^{a_{1} t}+A_{2} e^{a_{2} t}+A_{3} e^{a_{3} t}\right. \\
& \left.+A_{4} e^{a_{4} t}\right) q^{3} w c^{0} /\left(w_{1}{ }^{3} w_{4}\right)
\end{aligned}
$$

ただし, $w_{1}=w_{2}=w_{3}, w=w_{1}+w_{2}+w_{3}+w_{4}$,

$$
\begin{aligned}
& 1 / A_{1}=\left(a_{1}-a_{2}\right)\left(a_{1}-a_{3}\right)\left(a_{1}-a_{4}\right), \\
& 1 / A_{2}=\left(a_{2}-a_{1}\right)\left(a_{2}-a_{3}\right)\left(a_{2}-a_{4}\right), \\
& 1 / A_{3}=\left(a_{3}-a_{1}\right)\left(a_{3}-a_{2}\right)\left(a_{3}-a_{4}\right), \\
& 1 / A_{4}=\left(a_{4}-a_{1}\right)\left(a_{4}-a_{2}\right)\left(a_{4}-a_{3}\right), \\
& a_{1}=-q / w_{1}, a_{2}=-2 q / w_{1}, a_{3}=-3 q / w_{1}, \\
& a_{4}=-4 q / w_{4}
\end{aligned}
$$

妒内のスラグは溶鋼の場合と異なり発泡状態にあり，排 滓孔付近では消泡と冷却による粘性の増加を伴い，また 妒内ガス压の変動によりスラグの流出流量の測定は難か しく，人員の都合からもスラグの滯留時間分布の実測は Fig. 5 にプロットした 2 回である.この測定結果から第 61 回実験の平均滞留時間は $8.3 \mathrm{~min}, 20 \mathrm{~min}$ 間の平均流 出流量は $11.9 \mathrm{~kg} / \mathrm{min}$, 第62回ではそれぞれ $6.1 \mathrm{~min}$, $11.7 \mathrm{~kg} / \mathrm{min}$ であつた。 スラグ滞留量は流量と平均㵲 留時間の積であるから，第 61 回では $99 \mathrm{~kg}$ ，第 62 回で は71 kg の滯留量となる。しかしこれらの值については 流出小レーサー量が投入量の $40 \%$ 程度しかないこと， 第 61 回実験の第 1 段炬造滓剂投入量 $12 \mathrm{~kg} / \mathrm{min}$ ，鉄 叙石投入量 $1 \mathrm{~kg} / \mathrm{min}$ ，第 62 回ではそれぞれ $13 \mathrm{~kg} /$ $\min , 1 \mathrm{~kg} / \mathrm{min}$ であること，前述のスラグ流量は磁着 分を除いた場合の值であり，実際の流量はそれぞれ 15 $\mathrm{kg} / \mathrm{min}, 18 \mathrm{~kg} / \min$ であことおよび流量の変動が士

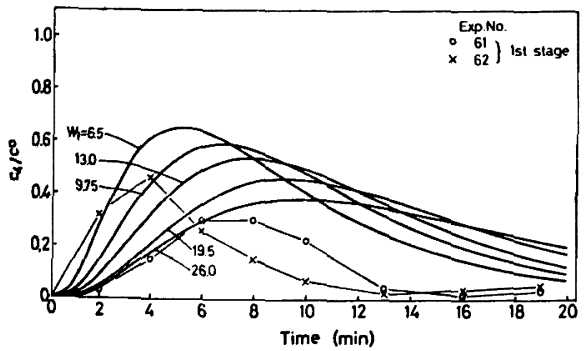

Fig. 5. Impulse response in slag phase based on back-mix reactors in series.
30\%はあることを考慮しなければならない，投入トレー サ一量の 40\% しか排㳯孔から流出されなかつた原因と して，投入位置が溶湯流入側スキンマーと最初のランス の間のため，十分掜找したにもかかわらずかなりの量が スキンマー側に吹き寄せられたことが考えられる．Fig. 5 の曲線は(28)式に打いて $w=91 \mathrm{~kg}, 4 q=13 \mathrm{~kg} / \mathrm{min}$ とした場合の滯留時間分布を $w_{1}$ を変えて計算した結果 である. 以上のことから大まかではあるが，シミュレー ションの対象とした操業のうち第 61 回実験のスラグ滞 留量は $w_{1}=13 \mathrm{~kg}, w_{4}=51 \mathrm{~kg}$ と仮定し, 第 58 回実 験の場合, 第 1 段炉の造滓郕投入量が $9 \mathrm{~kg} / \mathrm{min}$ のため 滯留量も比例して減るものと仮定して $w_{1}=10 \mathrm{~kg}, w_{4}$ $=40 \mathrm{~kg}$ として計算を行なつた.

\section{$3 \cdot 2 \cdot 3$ 流出流量の規定}

上述の混合特性の検討は各槽内の滞留量を一定として 行なつたが，製鋼炬は上部開放容器であるため溶湯流入 量の変動は滯留量の增減をもたらし, 反応の進行に影響 する．実炉では溶湯流入量の変動による炉内鋼浴液面の 上下は水平面を保つて起こるのに対し，モデルでは溶湯 は 1 つの槽で反応を終えてから次の槽へ流入するとして いるため, 流入量の変動に対する各槽の滞留量の増減に 時間遅れを有することになる．このことは溶湯が製鋼炉 に半量入つた時点で酸素吹精を開始する操業開始時のシ そュレーションでは特に問題となる. 本モデルでは炕内 4 槽の間に仮想の堰を設け，この堰による滯留量 $W_{h i}$ （i=1〜3）を越えた量が次槽への流量 $Q_{i \text { out }}$ となると仮 定して計算した.

$$
Q_{\text {iout }}=w_{i}-w_{h i}
$$

この仮定により炬内の溶湯液面を各槽ともほぼ同一に保 つととができる。すなわち定常状態においても各槽の滯 留量はわずかずつ異なる. 第 4 槽からの流出量 $Q_{\text {dout }}$ は 実炉の堰が炉内滯留量を一定に保つ機能をよく果たして いること，すなわち流入量の変動に対する液面の上下が 少ないことを考慮して，モデルでは第4 槽の仮想堰滯留 量 $W_{h 4}$ を越えた量の 2 乗*を次段への流出流量とした。

$$
Q_{\text {Aout }}=\left(w_{4}-w_{h 4}\right)^{2} \text {. }
$$

発泡状態にあるスラグの流出量の規定は，炬内ガス流 の影響が大と思われるがここでは溶湯の場合と同様に扱 つた.

$$
\begin{aligned}
& q_{\text {iout }}=w_{i}-w_{h i}, \quad(i=1 \sim 3) \\
& q_{\text {Aout }}=\left(w_{4}-w_{h 4}\right)^{2}
\end{aligned}
$$

(29)，(31) 式には比例係数 $1(1 / \mathrm{min})$ が，(30)，(32)式

*閔放殹における液頭と流量の関缧は, 四角殹の場合液頭の $3 / 2$ 乗に比 例し，三危垠の場合 $5 / 2$ 乘に比例するが，実妒の嚗は半径 $60 \mathrm{~mm}$ の桶 型で，溶湯はての上を深さ $18 \mathrm{~mm}$ 程度で流れているため四角堭と三角 殹の中間とみなして 2 乘に比例するとした。 
Table 1. Chemical composition of fluxes and iron ore.

\begin{tabular}{l|c|c|c|c|c|c|c|c|c|c}
\hline \multicolumn{1}{c|}{ Materials } & $\mathrm{CaO}$ & $\mathrm{SiO}_{2}$ & $\mathrm{MgO}$ & $\mathrm{T} . \mathrm{Fe}$ & $\mathrm{FeO}$ & $\mathrm{CaF}_{2}$ & $\mathrm{Al}_{2} \mathrm{O}_{3}$ & $\mathrm{CaCO}_{3}$ & $\mathrm{P}$ & $\mathrm{S}$ \\
\hline $\begin{array}{l}\text { Lime } \\
\text { Fluorspar }\end{array}$ & 81.05 & 7.35 & & & & & & 11.56 & 0.015 & 0.024 \\
$\begin{array}{l}\text { Silica } \\
\text { Iron ore }\end{array}$ & 0.06 & $\begin{array}{c}9.7 .9 \\
3.31\end{array}$ & 0.04 & 66.99 & 0.30 & & 1.67 & & 0.037 & 0.014 \\
\hline
\end{tabular}

には1(1/( kg・min))が掛かつているものとする.

溶湯の堰による滞留量は, 溶銑流入量 $130 \mathrm{~kg} / \min の$ 定常状態で $3 \cdot 2 \cdot 1$ で定めた滞留量を満足する值として $w_{h 1 \sim 3}=70 \mathrm{~kg}, w_{h 4}=390 \mathrm{~kg}$ とした. スラグについて は各ランスから造㴖剤が供給されていることを考虑して 造滓剂投入量 $9 \mathrm{~kg} / \min$ の場合 (第58回実験), $w_{h 1}=$ $7 \mathrm{~kg}, w_{h_{2}}=3 \mathrm{~kg}, w_{h 3}=1 \mathrm{~kg}, w_{h_{4}}=35 \mathrm{~kg}$ を用い, 12 $\mathrm{kg} / \min$ の場合(第61回実験), それぞれ $10 \mathrm{~kg}, 6 \mathrm{~kg}$, $4 \mathrm{~kg}, 47 \mathrm{~kg}$ とした.

\section{3 .3 熱損失}

実操業に関する熱精算の絬果, ランス冷却水が持ち去 る熱量が熱損の大部分を占めていることが判明したため モデルでは熱損を各槽から均等に分担するとして, 熱損 式を以下のごとく定義した。製鋼炉 1 段の熱損 $H l$ は各 槽の熱損 $H l_{i}$ の和であるから，

$$
H l=H l_{1}+H l_{2}+H_{3}+H l_{4}=4 \cdot H l_{i}
$$

各槽にお汁る反応熱 $\mathrm{Hr}_{i}$ は，各ランスの酸素吹精量は 等しいと考えられることから，

$$
\begin{aligned}
& H r=H r_{1}+H r_{2}+H r_{3}+H r_{4}=4 \cdot H r_{i} \\
&(33),(34) \text { 式を }(19) \text { 式に代入すると, } \\
& H l_{i}=H L\left(H_{i n} / 4+H r_{i}\right) \cdots \cdots \cdots . . .
\end{aligned}
$$

流入熱量 $H_{i n}$ は吹精酸素，造滓剂などの各槽ごとに外 部から流入する物質の熱量 $h_{i n i}$ と，製鋼炉入の流入溶 湯の熱量 $h_{H M}$ の和であるので熱損は最終的に次式とな る.

$$
H l_{i}=H L\left(h_{H M} / 4+h_{i n i}+H r_{i}\right)
$$

\section{4 造㳯剂}

吹精ランスから酸素上同時供給される粉体の造涬剂に 含まれている $\mathrm{CaCO}_{3}$ と，第 1 段炉の第 3 ランスの前に $1 \mathrm{~kg} / \min$ の割合で投入される鉄鉱石 $\left(\mathrm{Fe}_{2} \mathrm{O}_{3}\right)$ の分解 と生成ガスによる炉内の㨨拌に対する寄与を以下のよう に仮定した. $\mathrm{CaCO}_{3}$ は最終的に $\mathrm{CaCO}_{3}=\mathrm{CaO}+\mathrm{CO}+$ $\mathrm{O}_{2} / 2$ に分解寸るとし, 発生した CO は（1)，（2）式 の $V_{\mathrm{CO}}$ の一部として攪拌に寄与するが, 遊離した酸素 は摫拌には直接は関係せず,供給酸素 $\mathrm{O}_{2 \text { in }}$ の一部をなす ものとした. $\mathrm{Fe}_{2} \mathrm{O}_{3}$ の分解 $\mathrm{Fe}_{2} \mathrm{O}_{3}=2 \mathrm{FeO}+\mathrm{O}_{2} / 2$ で生 じた酸素も同様に $\mathrm{O}_{2 \ln }$ の一部として加えた.

反応熱の式 (18)の最終項 $h_{D}$ は上記の反応の分解熱と
複塩生成熱の和である. 投入鉄鉱石はすべて第 3 槽に入 るとして計算した，造滓剂（粉体）と鉄鉱石（ $<5 \mathrm{~mm})$ は炉内へ投入後ただちに滓化するとした.

\begin{tabular}{|c|c|c|c|c|c|}
\hline \multirow{2}{*}{\multicolumn{2}{|c|}{$\frac{\text { Operation number }}{\text { Stage of furnace }}$}} & \multicolumn{2}{|l|}{58} & \multirow{2}{*}{$\frac{59}{1}$} & \multirow{2}{*}{$\frac{60}{1}$} \\
\hline & & 1 & 2 & & \\
\hline \multicolumn{2}{|c|}{$\begin{array}{r}\text { Hot metal flow rate } \\
\qquad(\mathrm{kg} / \mathrm{min})\end{array}$} & 130 & 130 & 130 & 130 \\
\hline \multicolumn{2}{|c|}{$\begin{aligned} \text { Oxygen blow rate } \\
\\
$\[ \left(\mathrm{Nm}^{3} / \mathrm{min}\right) \]$ \\
\end{aligned}$} & 2.2 & 4.4 & 2.4 & 2.4 \\
\hline \multicolumn{2}{|c|}{$\begin{array}{l}\mathrm{Feed} \mathrm{rate}(\mathrm{kg} / \mathrm{min}) \\
\mathrm{CaO}: \mathrm{CaF}_{2}: \mathrm{SiO}_{2}\end{array}$} & $\left|\begin{array}{r}9 \\
5: 1: 0\end{array}\right|$ & $\left|\begin{array}{r}4 \\
4: 1: 1\end{array}\right|$ & $\left|\begin{array}{r}10 \\
5: 1: 0\end{array}\right| 5$ & $\begin{array}{r}12 \\
5: 1: 0\end{array}$ \\
\hline \multicolumn{2}{|c|}{$\begin{array}{l}\text { Iron ore feed rate } \\
\qquad(\mathrm{kg} / \mathrm{min})\end{array}$} & 1 & 0 & 1 & 1 \\
\hline \multicolumn{2}{|c|}{$\begin{array}{l}\text { Total number } \\
\text { Lance for oxygen } \\
\text { only } \\
\begin{array}{ll}\text { Height } & (\mathrm{mm}) \\
\text { Angle } & \left({ }^{\circ}\right)\end{array}\end{array}$} & $\begin{array}{r}4 \\
0 \\
150 \\
5\end{array}$ & $\begin{array}{r}5 \\
3 \\
160 \\
5\end{array}$ & $\begin{array}{r}4 \\
0 \\
150 \\
5\end{array}$ & $\begin{array}{r}4 \\
0 \\
150 \\
5\end{array}$ \\
\hline \begin{tabular}{l|l} 
Temp. & Pig iron \\
Hot metal
\end{tabular} & $\begin{array}{l}\left({ }^{\circ} \mathrm{C}\right) \\
\left({ }^{\circ} \mathrm{C}\right)\end{array}$ & $\begin{array}{ll}1450 \\
1530\end{array}$ & 1690 & $\left|\begin{array}{ll}1 & 380 \\
1 & 460\end{array}\right|$ & $\begin{array}{l}1400 \\
1490\end{array}$ \\
\hline $\begin{array}{l}\text { Chemical compo- } \\
\text { sition of pig } \\
\text { iron }(\%)\end{array}$ & $\begin{array}{r}\mathrm{C} \\
\mathrm{Si} \\
\mathrm{Mn} \\
\mathrm{P}\end{array}$ & $\begin{array}{l}3.80 \\
0.57 \\
0.55 \\
0.13\end{array}$ & & $\begin{array}{l}3.91 \\
0.40 \\
0.53 \\
0.12\end{array}$ & $\begin{array}{l}3.96 \\
0.54 \\
0.55 \\
0.10\end{array}$ \\
\hline $\begin{array}{l}\text { Chemical compo- } \\
\text { sition of hot } \\
\text { metal }(\%)\end{array}$ & $\begin{array}{l}\mathrm{C} \\
\mathrm{Si} \\
\mathrm{Mn} \\
\mathrm{P}\end{array}$ & $\left|\begin{array}{r}2.82 \\
<0.01 \\
0.29 \\
0.028\end{array}\right|$ & $\left|\begin{array}{r}0.04 \\
<0.01 \\
0.12 \\
0.010\end{array}\right|$ & $\left|\begin{array}{r}2.89 \\
0.01 \\
0.20 \\
0.018\end{array}\right|$ & $\begin{array}{r}3.10 \\
<0.01 \\
0.26 \\
0.027\end{array}$ \\
\hline $\begin{array}{l}\text { Chemical } \\
\text { composition of } \\
\text { slag }(\%)\end{array}$ & $\left|\begin{array}{c}\mathrm{CaO} \\
\mathrm{SiO}_{2} \\
\mathrm{P}_{2} \mathrm{O}_{5} \\
\mathrm{FeO} \\
\mathrm{Fe}_{2} \mathrm{O}_{3} \\
\mathrm{MnO} \\
\mathrm{MgO} \\
\mathrm{CaF}_{2}\end{array}\right|$ & $\begin{array}{r}51.3 \\
23.6 \\
2.7 \\
3.3 \\
1.9 \\
3.9 \\
3.6 \\
11.3\end{array}$ & $\begin{array}{r}25.4 \\
17.3 \\
0.8 \\
26.9 \\
12.4 \\
5.2 \\
13.7 \\
6.7\end{array}$ & $\begin{array}{r}50.4 \\
20.3 \\
2.7 \\
9.9 \\
4.5 \\
4.2 \\
2.0 \\
7.8\end{array}$ & $\begin{array}{r}61.3 \\
14.1 \\
1.9 \\
5.3 \\
6.0 \\
5.5 \\
2.2 \\
11.5\end{array}$ \\
\hline Oxygen efficiency & $(\%)$ & 83.7 & 86.0 & 80.5 & 83.0 \\
\hline Heat loss & $(\%)$ & 7.8 & 7.3 & 9.3 & 10.6 \\
\hline
\end{tabular}

\section{5 計算結果}

$3 \cdot 2 \sim 3.4$ で述べたモデルの修正を行い，第 58 回と第 59 回連続製鋼実験の第 1 段炉の定常状態の操業結果を

Table 2. Operating conditions and results. 
Table 3. Constants and out put data calculated by complex method.

\begin{tabular}{|c|c|c|c|c|}
\hline \multicolumn{2}{|c|}{$\begin{array}{l}\text { Operation number- } \\
\text { stage }\end{array}$} & $58-1$ & $59-1$ & $\begin{array}{l}\text { Data for } \\
\text { simulation }\end{array}$ \\
\hline $\begin{array}{l}\text { System } \\
\text { constants }\end{array}$ & $\begin{array}{l}\alpha_{\mathrm{CO}} \\
d_{\mathrm{O}} \\
\alpha_{\mathrm{Si}} \\
\alpha_{\mathrm{Mn}} \\
\alpha_{\mathrm{P}} \\
\mathrm{OE} \\
X\end{array}$ & $\begin{array}{l}0.00019 \\
0.0010 \\
0.0071 \\
0.0240 \\
0.0116 \\
0.856 \\
0.38\end{array}$ & $\begin{array}{l}0.00020 \\
0.0010 \\
0.0063 \\
0.0218 \\
0.0080 \\
0.808 \\
0.34\end{array}$ & $\begin{array}{l}0.00018 \\
0.0010 \\
0.0070 \\
0.0240 \\
0.0120 \\
0.800 \\
0.40\end{array}$ \\
\hline $\begin{array}{l}\text { Out put } \\
\text { data }\end{array}$ & $\mid$\begin{tabular}{c|} 
Temp. $\left({ }^{\circ} \mathrm{C}\right)$ \\
$\mathrm{C}(\%)$ \\
$\mathrm{Si}(\%)$ \\
$\mathrm{Mn}(\%)$ \\
$\mathrm{P}(\%)$ \\
$\mathrm{FeO}(\%)$
\end{tabular} & \begin{tabular}{l|}
1506 \\
2.59 \\
0.008 \\
0.266 \\
0.032 \\
5.6
\end{tabular} & $\begin{array}{l}1431 \\
2.73 \\
0.006 \\
0.159 \\
0.021 \\
13.5\end{array}$ & \\
\hline
\end{tabular}

もとに，3.1に述べた未定の各種定数の探索を以下゙のよ うに行なつた。数値計算に用いた操業上既知の定数とし て, 造滓剂の分析值を Table 1 に, 操業条件とその結 果を Table 2 に示す.

最適值探索の副プログラムである連続製鋼法モデルの 計算は, $0.025 \mathrm{~min}$ 間隔でオイラー法で行ない，コンプ レックス法の主プログラムから送られてくる1組の未定 定数に関し, $20 \mathrm{~min}$ 繰返し計算の結果を目的関数に咲 り返し判定を行うことを1回として，120 回繰返し探索 して得られた定数値を Table 3 に示す. Table 2 の実 㖪值と比較して, 温度と $\mathrm{C}$ 濃度がかなりよい近似を示し ているのに対し， $\mathrm{Mn}$ と $\mathrm{P}$ 濃度は実験值と 10〜20\%の 差があるが，これはスラグ温度を鋼浴温度と等しいとし たことにも一因があると思われる．計算誤差を修正才イ ラー法によるモデル計算と比較した結果は，使用した繰 返し時間間隔では実用上差異は涩められなかつた。

酸素効率 $\mathrm{O} E$ は (12)，(13)，(14) 式の $\mathrm{O}_{2 \mathrm{in}}$ に掛か るとしてモデルに組込んだが， $\mathrm{OE}$ として実炉の物質収 支による值を用いず末定定数の1つとした理由は，スラ グ分析試料の調整段階で磁着分の除去を行なつているた め, 実際のスラグ中の酸化鉄含有量が分析值より大なる 可能性があること，排ガス流量の計測が行なえなかつた ことによる．製鋼反応は（FeO）-C-O の動的なバラ ンスの上に進行していくといえるが， Table 2 および Table 3 の結果を比較すると酸素効率の計算結果が実験 結果とほほ等しく，酸化鉄の值も実測值に対し $10 \%$ 程 度の範囲に納まつていることは，モデルに用いた仮定の 妥当性を意味するものと思われる．また問題の多い高炭 素域におけるスラグの分析試料の調整も適切であつたと 言える.

シミュレーションに用いた值を.Table 3 の右端に示
したが，酸素分配率 $X$ を計算絬坚より大としたのは，X は吹精条件の関数であり，操業開始時のランス・溶湯間 距離が定常状態より朔れているたる，酸化鉄の生成にま わる酸素量が增大寸ると考えられることによる.

\section{4. 操業開始時のシミュレーション}

一般に遇㭠反心装置の操業開始を效率よく行なわせる には非定常状態在扱らため，倠置およびその中で起こる 及応の特性に関し十分交理解が必要とされる。このこと は金材技研式連続製鋼法心ついても同校てあり，より文 全で効率的な操業開始方法が検討されてきたが，その確 立は単に操業開始のみでなく，連続操業中における一定 常状態から次の定常状態への暧移時間を短縮与る上でも 指針を与えるものである。ここでは 3 で述べた定常状態 基に作成したモデルの非定常域に対する適応性を検討 し，またモデルによる未経騃の操業法開発の可能性を検 討寸る意川林で, 実操業の操業開始時と, 半回分式操業開 始法上名付けた仮想の操業法のシミュレーションをそれ ぞれ行なつたがその結果について述べる.

\section{$4 \cdot 1$ 実操業の操業開始}

金材技研式連続製鋼法の操業開始は，女ず $1 \sim 2 \mathrm{hr}$ 前

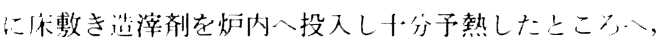
溶銑の流入を開始 $(0$ 時とする) し，製鋼灯滞留量の半量 $(500 \mathrm{~kg})$ まで溶湯がたまつた時点で，てれまでランス， ズルの閉塞防止のために少量吹いていた酸素量を規定值 に上げ，約 $1 \mathrm{~min}$ 後浩洋削の酸素による同時供給を開始 し，合せて鉄鉱石の投入開始という手順で行なわれる。 第，2段炉の操業開始も同様であるが，溶湯が第，段炉に 入る時点では賗銑炉からの溶㑥流量が規定值にコントロ 一ルされているたか，スタートアップに第1段炉より 2

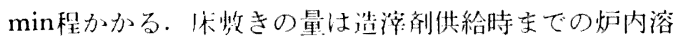
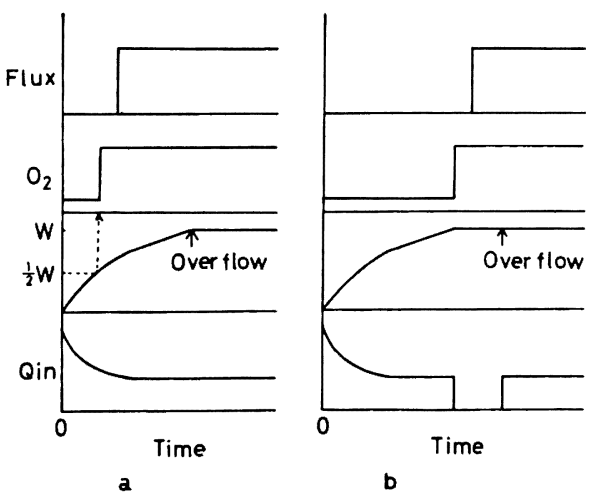

Fig. 6. Schematic representations of a : NRIM start-up and b: semi-batch start. 
Table 4. Input data for start-up simulations.

\begin{tabular}{|c|c|c|c|c|c|c|c|c|c|c|c|c|c|}
\hline Run & & $58-$ & & & & & & & & & $61-$ & & \\
\hline Lance & 1 & 2 & 3 & 4 & 1 & 2 & 3 & 4 & 5 & 1 & 2 & 3 & 4 \\
\hline $\begin{array}{l}\text { Metal under weir } \\
(\mathrm{kg})\end{array}$ & 70 & 70 & 70 & 390 & 20 & 20 & 20 & 20 & 390 & 70 & 70 & 70 & 390 \\
\hline Slag under weir $(\mathrm{kg})$ & 7 & 3 & 1 & 35 & 7. & 5 & 3 & 1 & 35 & 10 & 6 & 4 & 47 \\
\hline $\begin{array}{l}\text { Initial flux weight } \\
\qquad(\mathrm{kg})\end{array}$ & 10 & 10 & 10 & 10 & 8 & 8 & 8 & 8 & 8 & 10 & 10 & 10 & 10 \\
\hline $\begin{array}{l}\text { Half of metal } \\
\text { hold-up }\end{array}$ & 100 & 100 & 100 & 200 & 75 & 75 & 75 & 75 & 200 & 100 & 100 & 100 & 200 \\
\hline
\end{tabular}

湯量を考虑して決められた。

Fig. 6 （a ）は上記の方法を図式化したものである. シミュレーションの対象とした第 58 回実験の第 $1 ， 2$ 段炬と第 61 回実験の第 1 段炉の堰下滯留量, 酸素吹精 開始時の床敷き造洋剤の各槽内滞留量および各ランスか らの造䐠刜供給量を Table 4 に示す. 第 2 段炉の造 涬戍は溶湯流入側から第 $2 ， 3$ 番の 2 本のランスからの 夕供給されているが，モデルでは第 2 ランスからの造渼 用供給量のうち $0.5 \mathrm{~kg} / \min$ が第1ランスから吹込まれ ると仮定した．また第 2 段炉の溶湯滯留量は 5 本のラン スが第 1 段炉の 4 本のランス取付位置とほぼ同一範囲に 取付けられていることから，第1 段炉の入口側 3 本分の 滞留量を 4 本で分担するとして 3.2 を参考に決定した。 第 2 段炉のスラグ滞留量はこの段の造滓剂供給量が第 1 段炉よりも少ないが，排滓口高さは第 1，2段炉とも同 一であることから，堰下滯留量は第 1 段炉と同等である として Table 4 の値とした.

各実験の操業開始時における溶湯流量, 成分および温 度の時間変化をインプットデータとして読け込みシミュ レートした結果を Fig. 7〜9 に示す. 装置規模が小さ く安定した操業の難かしい実験であることを考えると， モデルは実測值をかなりよく代表しているといえる. $P_{\text {eq }}$ の計算に BALAJIVA ${ }^{19}$ の式を用いた場合を Fig. 7 の 点線で示したが，実測值との差が大きく，本モデルでは

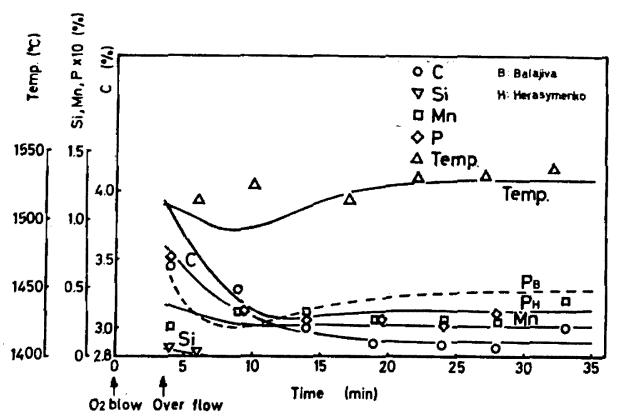

Fig. 7. Simulated results of the 1st stage in exp. 58.
Herasymenko の式がより適切であつたといえるが，ス ラグ温度に関する正確な情報があれば探索による各未定 定数の值む変わることが考えられ，それにより他の平衡 関係式が現象をより適確に表わす可能性もあると思われ る.

Fig. 8 に示す第 58 回実験の第 2 段炉のシミュレーシ ョンは第 1 段炉のシミュレーションの結果をインプット データとして行なつた．実測值と比べて 9 本のランスを 通した計算結果としてはかなりよく近似しているといえ る.

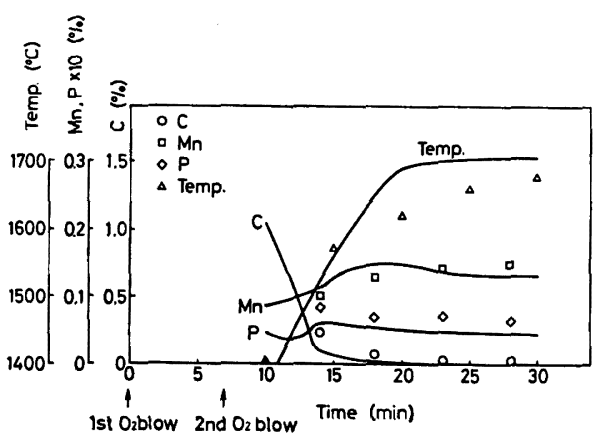

Fig. 8. Simulated results of the 2nd stage in exp. 58.

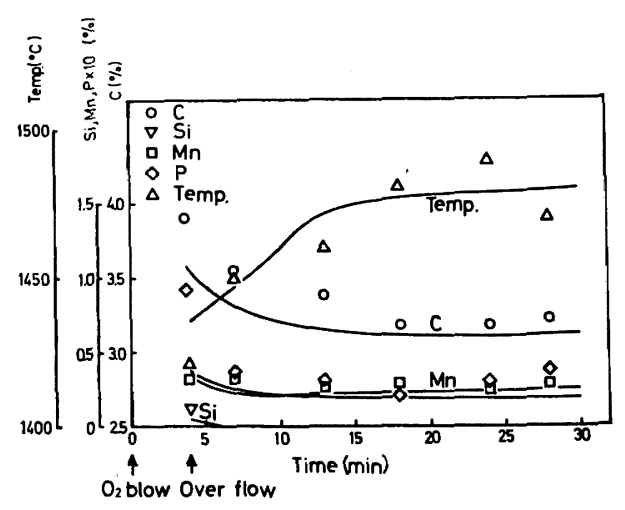

Fig. 9. Simulated results of the lst stage in exp. 61. 


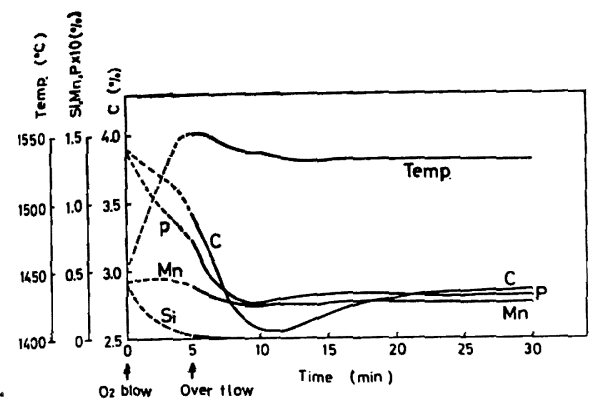

Fig. 10. Simulation of semi-batch start besed on exp. 58 data.

以上の結果から定常状態に関して求めた抵抗俰数が, 操業開始時という非定常状態のシミュレーションにも適 用できることが判明した．このことは金材技研式連続製 䤡装置を反応に関して定係数系として扱えることを意味 し，モデルによる最適制御法の確立の可能性を示唆する ものといえる、また炉内の覧拌におよぼす酸素シェット と生成 $\mathrm{CO}$ ガスの上昇の効果は, 質量流量で等価とみな してもモデリングの上では支障ないことが判明した.

\section{2 半回分式操業開始}

第 58 回実験の第 1 段炉と同一の操業条件で，操業開 始を Fig. 6 (b) に示す半回分式, すなわち炉内に溶湯 が $1000 \mathrm{~kg}$ 滯留したところで溶銑の流入を中止し, 規定 流量の酸素吹精を開始し, $5 \mathrm{~min}$ 後に溶銑の流入を再開 し連続操業に入るとした場合のシミュレーション結果在 Fig. 10 に示す. 半量で操業開始する実操業の場合に比 較して出湯成分の変動が少なく, 定常化への遷移時間も 短かくてすむことがわかる. 溶銑供給系が流量の断続, 制御を容易に行なえる場合には，この操業開始法は有利 といえる。なお溶湯が炉内を一杯に満たし溢流のない状 態では仮想堰はなく炉内は均一に攪找されているとして 計算した。実際にこの方法でスタートした操業例がない ため計算結果に対する判断は難しいが, 半量スタートの 場合と異なり流入溶湯による炉況への影響が少ないと思 われることを考慮すると，この結果は妥当なものと思わ れる.

\section{5. 結}

\section{言}

金材技研式連続製鋼法の製鋼反応を物質移動律速であ るとし, 移動量は濃度差と供給あるいは生成されたガス 流量の関数であるとして，連続製鋼法のモデルを作成し それを用いて操業開始時のシミュレーションを行なつた が，その計算結果は実操業の結果をかなりよくシるェレ 一トしらることが確認された. とくに炉内の攪找がガス
流量の関数であるとしたことは，製鋼反応を動的に理解 する上で非常な助けとなることがわかつた。最適化法に より得られた抵抗定数は, 操業開始時という非定常域の シミュレーションにおいてもよい近似をもたらしたが， このことは連続操業の一定常状態加ら次の定常状態入の 遷移域の制御法の確立, あるいは脱 $\mathrm{C}$, 脱 $\mathrm{P}$ に最適な炋 の設計と操業方法を開発する上で一つの指針を与えたも のと思われる. 現在このモデルの思想に基ゔいて, 連繶 予備脱燐法の検討を進めている.

$$
\text { 記 号 }
$$

$C, c:$ 溶湯とスラグ中のトレーサー濃度 $($ 一)

$C^{\mathbf{0}}, c^{\mathbf{0}}$ : 溶湯とスラグ巾の初期トレーサー濃度 (一)

$C_{j}: j$ 元秦の濃度 $(-)$

$C_{p}:$ 比熱 $\left(\mathrm{kcal} / \mathrm{kg} \cdot{ }^{\circ} \mathrm{C}\right)$

$G, g:$ 溶湯とスラグ層の伝達関数

$H:$ 炉内物質の熱含量 $(\mathrm{kcal})$

$H_{\text {in }}$, out : 流入, 流出熱量 $(\mathrm{kcal} / \mathrm{min})$

$H L:$ 熱損失係数 $(-)$

$H l:$ 熱損 $(\mathrm{kcal} / \mathrm{min})$

$H r$ : 反応熱発生速度 $(\mathrm{kcal} / \mathrm{min})$

$\Delta H:$ 反応熱 $(\mathrm{kcal} / \mathrm{kg})$

$h_{D}$ : 造滓剂と鉄鉱石の分解熱と複塭生成熱の和 (kcal/ $\mathrm{min}$ )

$h_{H M}$ : 流入溶湯の有する熱量 $(\mathrm{kcal} / \mathrm{min})$

$K:$ 平衡定数 (一), ただし $K_{\mathrm{CO}}(\mathrm{atm})$

$m:$ 原子, 分子量 $(\mathrm{g} / \mathrm{mol})$

$N:$ モ分率 (- )

$\mathrm{O}_{2 \text { in }}$ : 供給酸素量 $(\mathrm{kg} / \mathrm{min})$

$\mathrm{O} E$ : 酸素効菜 (一)

$P$ : 気生 (atm)

$Q:$ 溶湯流量 $(\mathrm{kg} / \mathrm{min})$

$q$ : 造漳剂, 鉄鉱石， スラグ流量 $(\mathrm{kg} / \mathrm{min})$

$R:$ 移動抵抗 $(\mathrm{min} / \mathrm{kg})$

$s:$ ラプラス演算吇.

$T:$ 絶対温度 $\left({ }^{\circ} \mathrm{K}\right)$

$J T:$ 標準温度々の温度差 $\left({ }^{\circ} \mathrm{C}\right)$

$t:$ 時間 $(\mathrm{min})$

$U:$ 物質流量 $(\mathrm{kg} / \mathrm{min})$

$V:$ 気体流量 $(\mathrm{kg} / \mathrm{min})$

$W, w:$ 溶湯，スラグ滯留量 $(\mathrm{kg})$

$W_{h}, w_{h}$ : 溶湯，スラグの仮想堰滯留量 $(\mathrm{kg})$

$X:$ 酸素分配係数 $($ - $)$

$\alpha:$ 抵抗係数 $(-)$

$\gamma:$ 活量係数 $(-)$

添字 
$\mathrm{CO}$ : 溶湯・スラグ反応

eq : スラグに平衡する濃度

$i:$ ランス (槽) の番号

in : 流入

$j:$ : 溶湯・スラグ反応に扰ける $\mathrm{O}, \mathrm{Si}, \mathrm{Mn}, \mathrm{P}$

$k$ : 酸化物, $\mathrm{SiO}_{2}, \mathrm{MnO}, \mathrm{P}_{2} \mathrm{O}_{5}$

$M: \mathrm{Si}, \mathrm{Mn}, \mathrm{P}(-)$

$n:$ 流入物質

$\mathrm{O}:$ 酸素

$\mathrm{O}_{2}:$ 気体酸素

out : 流出

$p:$ 流出物質

*：ガス・溶湯界面

\section{文献}

1) 中川, 吉松, 上田, 三井, 福沢, 佐藤, 尾岎: 鉄 と鋼, 59 (1973), p. 414

2 ) L. S. Darken: Basic Open Hearth Steelmaking, (1951), p. 592 [AIME]

3 ) H. Krainer: 鉄と鋼, 51 (1965), p. 1194

4) V. I. サボイスキー: 鋼精鍊過程の理論 (訳), (1971)， p. 99 [日本学術振興会]

5 ) 丹羽, 横川: 鉄已銅, 52 (1966)， p. 505

6 ) 浅井, 鞭: 鉄と鋼, 55 (1969), p. 122

7 ) $S$. Okano, $J$. Matsuno, $H$. Oor, $K$. Tsuruoka,
T. Koshikawa and $A$. Okazaki: Proc. of Int. Conf, on the Sci. and Tech. of Iron and Steel (1970), p. 227, Tokyo

8 ) D. J. Price: Chem. Met. of Iron and Steel by ISI, (1973), p. 112, London

9) D. L. MicBride: Basic Open Hearth Steelmaking, 3rd ed. (1964), p. 948 [AIME]

10) 手墳, 山口, 稲富: 鉄と铜, 56 (1970), S. 74

11) 学振製鋼 19 委：製鋼反応の推奨平衡値, (1968)，[日刊工業新聞社]

12) P. Herasymenko and G. E. Speight: JISI, 166 (1950), p. 169

13) J.F. Elliot and $F . W$. Luerssen: Trans. AIME, 203 (1955), p. 1129

14) $J . F$. Elliott, $M$. Gleiser and $V$. RamakRISHNA: Thermochemistry for Steelmaking, (1963), p. 586 [Addison-Wesley Publishing Co.]

15) M. J. Box: Computer J., 8 (1965), p. 42

16) $G . S . G$. Beveridge and $R$. S. Schechter: Optimization: Theory and Practice, (1970), p. 453 [McGraw-Hill Book Co.]

17) J. Kowalik and $M . R$. Osborne, 山本, 小山 (共訳)：非線形最適化問题，(1970)， p. 31 [培 風館]

18) 上田, 三井, 中川, 吉松: 日本鉱業会誌, 89 (1973), p. 545

19) $K$. Balajiva and $P$. Vajragupta: JiSI, 155 (1947), p. 563 